\title{
IMPLEMENTASI PENGGUNAAN DANA DESA UNTUK MENINGKATKAN PERTUMBUHAN EKONOMI DI DESA SONGAN B
}

\author{
Ni Kadek Duri Listya Dewi ${ }^{1}$, Naswan Suharsono², Wayan Suwendra ${ }^{3}$ \\ Program Studi Pendidikan Ekonomi \\ Universitas Pendidikan Ganesha \\ Singaraja, Indonesia
}

\section{Email:durilistyadewi.id@gmail.com¹,naswansuharsono@undiksha.ac.id², Wayan.suwendra@undiksha.ac.id ${ }^{3}$}

\begin{abstract}
Abstrak
Penelitian ini bertujuan untuk mengetahui implementasi penggunaan dana desa ditinjau dari indikator pelayanan publik, perekonomian desa, dan pengentaskan kemiskinan dalam upaya meningkatkan pertumbuhan ekonomi di Desa Songan B, Kintamani, Bangli. Jenis penelitian ini adalah penelitian deskriptif dengan pendekatan kuantitatif. Populasi dalam penelitian ini adalah kepala keluarga yang tinggal di Desa Songan B berjumlah 2591 orang dan sampel sebanyak 96 orang dengan tehnik pengambilan sampel menggunakan proportional random sampling. Data dikumpulkan dengan metode kuesioner dan dokumentasi dengan analisis data yaitu analisis deskriptif. Hasil penelitian menunjukan bahwa implementasi penggunaan dana desa ditinjau dari indikator pelayanan publik dikategorikan sangat baik dengan total skor 8705, implementasi penggunaan dana desa ditinjau dari indikator perekonomian desa dikategorikan sangat baik dengan total skor 7306, implementasi penggunaan dana desa ditinjau dari indikator mengentaskan kemiskinan dikategorikan sangat baik dengan total skor 3279 .
\end{abstract}

Kata kunci : Dana desa, pertumbuhan ekonomi, Songan B

\begin{abstract}
This study aims to determinethe implementation of the use of village funds in terms of indicators of public services, the village economy, and poverty alleviation in an effort to increase economic growth in the village of Songan B, Kintamani, Bangli. This type of research is descriptive research with a quantitative approach. The population in this study were 2591 people who lived in Songan B Village and a sample of 96 people with sampling techniques using proportional random sampling. Data collected by questionnaire and documentation method with data analysis, namely descriptive analysis. The results showed that the implementation of the use of village funds in terms of public service indicators was categorized very well with a total score of 8705 , the implementation of village funds in terms of village economic indicators was categorized very well with a total score of 7306 , implementation of village funds in terms of poverty alleviation indicators was very good with a total score of 3279 .
\end{abstract}

Keywords: Village funds, economic growth, Songan B 


\section{PENDAHULUAN}

Di era pasar global sekarang ini setiap negara harus mampu meningkatkan pondasi-pondasi ekonomi agar mampu bersaing dengan negara lain. Setiap negara mempunyai cara sendiri untuk mengupayakan pertumbuhan perekonomiannya. Seperti di Indonesia melalui strategi pembangunan dimana peningkatan pemerataan pembangunan beserta hasil-hasilnya melalui arah kebijakan pembangunan sektoral dan kinerja masyarakat terutama di pedesaan. Pembangunan desa merupakan sebagai subjek pembangunan, dan sebagai gerakan masyarakat dalam melaksanakan pembangunan yang dilandasi oleh kesadaran untuk meningkatkan kehidupan yang lebih baik.Diketahui bahwa hampir semua penduduk Indonesia bertempat tinggal di pedesaan. Dengan jumlah penduduk dan komponen alam yang potensial akan mendapatkan aset melalui dana desa. Sehingga dalam penerapannya dana desa harus sesuai dengan peraturan pemerintah.

Dalam suatu implementasi perlu dukungan sumber daya manusia maupun sumber daya material. Implementasi bermuara pada aktivitas, aksi, tindakan, atau adanya mekanisme suatu sistem, implementasi bukan sekedar aktivitas tetapi suatu kegiatan terencana untuk mencapai tujuan Nurdin (2002).

Salah satu program pemerintah dalam mendukung pembangunan desa yaitu dengan mengeluarkan dana desa sebagai salah satu sumber pendapatan desa yang bersumber dari APBN dana desa adalah dana yang bersumber dari Anggaran Pendapatan dan Belanja Negara yang diperuntukan bagi desa dan desa adat yang di transfer melalui APBD (Suharyono, 2018).

Dana desa diharapkan dapat memberi tambahan energi bagi desa dalam melakukan pembangunan dan pemberdayaan desa, menuju desa yang kuat, maju dan mandiri. Undang-undang No. 6 Tahun 2014 tentang desa, tujuan dana desa yaitu meningkatkan pelayanan publik desa, mengentaskan kemiskinan, memajukan perekonomian desa, mengatasi kesenjangan pembangunan antardesa, dan memperkuat masyarakat desa sebagai subjek dari pembangunan yang nantinya akan mampu meningkatkan pertumbuhan ekonomi di desa menurut undang-undang No. 6 Tahun 2014.

Untuk meningkatkan pertumbuhan ekonomi perlu juga meningkatkan pelayanan publik yang ada di Desa Songan B. Pelayanan publik adalah segala kegiatan pelayanan yang dilaksanakan oleh penyelenggara pelayanan umum sebagai upaya untuk pemenuhan kebutuhan penerima pelayanan dalam pelaksnaaan ketentuan peraturan perundang-undangan

Tujuan dana desa yang ketiga adalah untuk mengentaskan kemiskinan. Secara umum kemiskinan diartikan sebagai kondisi ketidakmampuan pendapatan dalam mencukupi kebutuhan pokok sehingga kurang mampu untuk menjamin kelangsungan hidup (Suryawati, 2004)

Pertumbuhan ekonomi dipengaruhi oleh beberapa faktor diantaranya faktor sumber daya manusia, sumber daya alam, faktor ilmu pengetahuan dan teknologi, faktor budaya, dan faktor sumber daya modal. Pertumbuhan Ekonomi ialah suatu proses perubahan kondisi perekonomian suatu Negara secara berkesinambungan menuju keadaan yang lebih baik selama periode tertentu (Windhu, 2018). Menteri Desa, Pembangunan Daerah Tertinggal, dan Transmigrasi (Mendes PDTT), Eko Putro Sandjojo, menyebutkan ada dua macam jenis pembangunan di desa. Pertama, ada yang langsung berdampak untuk pertumbuhan ekonomi kemudian yang kedua, pembangunan yang berdampak pada peningkatan kualitas hidup dasar masyarakat desa. Dana desa akan fokus menunjang perekonomian desa yang bisa meningkatkan pertumbuhan ekonomi adalah program membuat jalan raya, pasar, jembatan, irigasi, mengembangkan Badan Usaha Milik Desa (BUMDes), dan membangun Sarana Olahraga Desa (Raga Desa).

Pemanfaatan dana desa tak sekedar membangun insfrasktuktur, tapi juga meningkatkan perekonomian warga. Beberapa desa disebut suskes memberdayakan dana desa yang dikucurkan dari pemerintah pusat untuk 
menjadi sumber penghasilan bagi warganya. Diantaranya Desa Ponggok, Desa Tirtinirmolo, Desa Tajun, Desa Karang Kandiri, Desa Kampar, Desa Bleberan, Desa Landih, Desa Pakisan, Desa Kedungprimpen dan Desa Tunjung. Desa-desa tersebut menggunakan dana desa untuk mengelola potensi-potensi yang ada seperti potensi wisata, pertanian, simpan pinjam dan lainnya. UndangUndang Nomor 6 Tahun 2014 tentang desa menyebutkan bahwa : desa adalah kesatuan masyarakat hukum yang memiliki batas wilayah yang berwenang untuk mengatur dan mengurus urusan pemerintah, kepentingan masyarakat setempat berdasarkan prakarsa masyarakat, hak asal-usul, dan hak tradisional yang diakui dan dihormati dalam sistem pemerintahan Negara Kesatuan Republik Indonesia.

Suatu negara dapat dikatakan makmur ketika pembangunan ekonominya berlangsung lancar. Tidak hanya di wilayah perkotaan, pembangunan ekonomi juga selayaknya dilakukan di wilayah pedesaan. Pembangunan nasional bisa dikatakan lancar bila mampu mencakup tingkat yang paling bawah, yakni di pedesaan masingmasing. Desa harus mampu mengelola dana desa yang diberikan dengan seefektif dan seefisien mungkin. Dana harus tepat guna dan tepat sasaran. Desa diberikan wewenang yang lebih luas untuk memanfaatkan dana desa ini demi sepenuhnya kemakmuran dan kemajuan desanya.

Desa Songan merupakan desa yang berada di Kecamatan Kintamani Kabupaten Bangli. Desa ini terletak di kawasan lereng Gunung Batur dan Danau Batur. Masyarakat di Desa Songan sebagian besar mata pencaharianya sebagai petani, pemandu wisata dan lainya. Desa Songan memiliki potensi ekonomi yang sangat besar yang seharusnya mampu dikelola untuk meningkatkan pendapatan masyarakat. Potensi yang ada di Desa Songan diantaranya, potensi pertanian dengan lahan yang sangat subur, potensi wisata dengan pemandangan alam yang indah, pertambangan pasir. Melalui program pemerintah dengan pemanfaatan dana desa diharapkan potensi-potensi ekonomi yang ada di Desa Songan mampu dimanfaatkan dengan semaksimal mungkin demi pertumbuhan ekonomi dan kesejahteraan masyarakat di Desa Songan.

Desa Songan terdiri dari dua desa yaitu Desa Songan A dan Desa Songan B. Desa ini tergabung dalam satu wilayah namun, secara kedinasan terbagi menjadi dua yang masing-masing memiliki kepengurusan yang berbeda dan memiliki dua kepala desa.

Desa Songan B dipimpin oleh seorang kepala desa yang bernama Jero Lanang, S. E. Jumlah Penduduk Desa Songan B tahun 2018 Sebanyak 10.391 terdiri dari 5.190 laki-laki dan 5.201 perempuan dengan jumlah kepala keluarga 2591 yang masing-masing tersebar dalam 18 banjar.

Berdasarkan hasil observasi, dengan adanya dana desa yang dikucurkan oleh pemerintah sudah sangat berdampak bagi kehidupan ekonomi di Desa Songan B. Dana desa tersebut digunakan untuk perbaikan jalan, pembuatan senderan, pembuatan rabat beton, penggunaan kapasitas lembaga, pengelolaan PAUD, pembangunan obyek wisata dan lainnya sehingga mobilitas ekonomi di Desa Songan B menjadi lancar, mempermudah penjualan hasil pertanian, menghasilkan generasi yang berpendidikan, dan lain-lain.

Berdasarkan latar belakang yang telah diuraikan tersebut, maka peneliti tertarik melakukan penelitian tentang "Implementasi Penggunaan Dana Desa untuk Meningkatkan Pertumbuhan Ekonomi di Desa Songan B. Adapun tujuan dari penelitian ini adalah untuk mengetahui implementasi penggunaan dana desa untuk meningkatkan pertumbuhan dkonomi di Desa Songan B.

\section{METODE}

Jenis penelitian ini adalah penelitian deskriptif dengan pendekatan kuantitatif. Penelitian deskriptif adalah penelitian yang bertujuan untuk memberikan atau menjabarkan suatu keadaan atau fenomena yang terjadi saat ini dengan menggunakan prosedur ilmiah untuk menjawab masalah secara aktual. Penelitian deskriptif digunakan untuk 
memperoleh informasi mengenai implementasi penggunaan dana desa untuk meningkatkan pertumbuhan ekonomi di Desa Songan B. Populasi penelitian ini berjumlah 2.591 Kepala Keluarga. Mengingat jumlah populasi penelitian ini lebih dari 100, maka untuk menentukan jumlah sampel responden menggunakan perhitungan dengan rumus Slovin.

$n=\frac{N}{1+2^{2}}$

(Umar, 2005)

Keterangan:

$\mathrm{n}=$ ukuran sampel

$\mathrm{N}=$ ukuran populasi

$\mathrm{e}=$ persen kelonggaran ketidaktelitian karena kesalahan pengambilan sampel yang masih dapat ditolerir atau diinginkan

Berdasarkan rumus di atas, maka jumlah sampel yang akan digunakan dalam penelitian in dapat dihitung sebagai berikut.

$\mathrm{N}=2.591$

$\mathrm{e}=10 \%$

$$
\begin{aligned}
\mathrm{n} & =\frac{2.591}{1+2.591 \cdot(0,1)^{2}} \\
& =\frac{2.591}{26,91} \\
& =96
\end{aligned}
$$

Jenis data dalam penelitian ini adalah data kuantitatif berupa angka-angka jawaban dari responden mengenai kuesioner dan menggunakan skala likert untuk mengukur implementasi penggunaan dana desa untuk meningkatkan pertumbuhan ekonomi di Desa Songan B.

Adapun sumber data yang dipergunakan dalam penelitian ini adalah data primer dan data skunder. Data primer adalah sumber data yang secara langsung memberikan data kepada pengumpul data (Sugiyono, 2012). Data primer dalam penelitian ini berupa angka-angka jawaban dari responden mengenai kuesioner implementasi penggunaan dana desa untuk meningkatkan pertumbuhan ekonomi di Desa Songan B.

Data sekunder adalah sumber data yang tidak memberikan informasi secara langsung kepada pengumpul data misalnya dengan membaca, mempelajari dan memahami melalui media lain yang bersumber dari buku maupun nama dokumen (Sugiyono, 2012). Dalam penelitian ini, data sekunder berupa data dokumen nama, data Keuangan Dana Desa, jumlah kepala keluarga Desa Songan B.

Instrumen penelitian yang digunakan adalah kuesioner. Data yang telah dikumpulkan digunakan sistem skor, dimana jawaban pertanyaan diberi skor dengan menggunakan skala likert. Skala likert digunakan untuk mengukur sikap, pendapat, dan persepsi seseorang atau sekelompok orang tentang fenomena sosial (Sugiyono, 2013). Dalam skala ini responden menyatakan persetujuannya dan ketidaksetujuannya terhadap sejumlah pernyataan yang berhubungan dengan obyek yang diteliti. Jawaban dari setiap item instrumen yang menggunakan skala likert mempunyai gradasi dari sangat positif sampai sangat negatif.

Untuk menguji validnya suatu data dilakukan pengujian validitas instrumen. Validitas dalam penelitian dijelaksan sebagai suatu derajat ketepatan alat ukur penelitian tentang isi atau arti sebenarnya yang diukur (Umar, 2005). Pengujian validitas dalam penelitian ini dilakukan dengan menggunakan Person Correlation yang terdapat dalam program SPSS 24.0 for Windows. Instrumen penelitian dikatakan valid apabila $r_{\text {hitung }}$ (corrected item total corelation) $>r_{\text {tabel }}$ dan kuisioner dikatakan tidak valid apabila $r_{\text {hitung }}<r_{\text {tabel }}$ (Sugiyono, 2013).

Untuk menguji reliabelnya suatu data dilakukan pengujian reliabilitas instrumen. Reliabilitas menunjuk pada satu pengertian bahwa suatu instrumen dapat dipercaya untuk digunakan sebagai alat pengumpulan data karena instrumen tersebut sudah baik. Instrumen yang sudah dapat dipercaya dan yang reliabel akan menghasilkan data yang dapat dipercaya (Suharsimi, 2010). Dalam penelitian ini, pengujian reliabilitas instrumen dilakukan dengan membandingkan nilai Cronbach Alpha yang diperoleh dari SPSS 24.0 for Windows dengan batas nilai Cronbach Alpha untuk mengukur instrumen yang reliabel. Pengujian statistik dengan menggunakan teknik statistik Cronbach Alpha instrumen dikatakan reliabel untuk mengukur variabel 
apabila memiliki nilai Cronbach Alpha lebih $>0,60$ (Sugiyono 2013).

Analisis data dalam penelitian ini yaitu analisis deskriptif karena peneliti ingin mengetahui gambaran tentang Implementasi dana desa. Penentuan rentang skala implementasi penggunaan dana desa untuk meningkatkan pertumbuhan ekonomi di Desa Songan B menggunakan skala likert. Skala likert digunakan untuk mengukur sikap, pendapat dan persepsi seseorang atau sekelompok orang tentang fenomena sosial. Penentuan rentang skala yang dapat ditetapkan hal-hal sebagi berikut (Sugiyono, 2011).

Rentang jawaban menggunakan skala likert 1 sampai 5 . Jumlah skor tertinggi (positif) adalah jumlah pernyataan dikali skala tertinggi. Jumlah skor terendah (negatif) adalah jumlah pertanyaan dikali skala terendah. Rumus rentang skala adalah:

$\mathrm{Cl}=\frac{\text { s.m. }}{l}$

(Sugiyono, 2011)

Keterangan:

$\mathrm{Cl} \quad=$ Interval Kelas

Range $=$ Selisih antara data terbesar dan terkecil

C = Jumlah alternatif jawaban setiap item

\section{Hasil dan Pembahasan \\ Hasil}

Implementasi Penggunaan dana desa untuk meningkatkan pelayanan publik ditinjau dari aspek tangible, realibility, responsiveness, assurance, emphaty. Selanjutnya hasil perhitungan mengenai implementasi penggunaan dana desa untuk meningkatkan pelayanan publik dapat dilihat pada tabel 1.

Tabel 1. Implementasi Penggunaan Dana Desa untuk Meningkatkan Pelayanan Publik.

\begin{tabular}{cccc}
\hline Keterangan & Skor Aspek & Range Skor & Kriteria \\
\hline Tangible & 1606 & $1305,6-1612,7$ & Setuju \\
Reliability & 1863 & $1612,8-1920$ & Sangat Setuju \\
Responsiveness & 1586 & $1305,6-1612,7$ & Setuju \\
Assurance & 1836 & $1612,8-1920$ & Sangat Setuju \\
Emphaty & 1814 & $1612,8-1920$ & Sangat Setuju \\
Skor total & 8705 & $8064-9600$ & Sangat Setuju \\
\hline
\end{tabular}

Berdasarkan tabel 1 di atas, dapat dijelaskan bahwa pelayanan publik pada aspek tangible memiliki skor total 1606. Jika dilihat pada kriteria pelayanan publik, maka pelayanan publik di Desa Songan B pada aspek tangible masuk dalam range skor 1305,6 - 1612,7 dengan kriteria setuju. Pelayanan publik pada aspek reliability memiliki skor total 1863. Jika dilihat pada kriteria pelayanan publik, maka pelayanan publik di Desa Songan B pada aspek reliability masuk dalam range skor 1612,8 1920 dengan kriteria sangat setuju. Pelayanan publik pada aspek responsiveness memiliki skor total 1586 . Jika dilihat pada kriteria pelayanan publik, maka pelayanan publik di Desa Songan B pada aspek responsiveness masuk dalam range skor 1305,6 - 1612,7 dengan kriteria setuju. Pelayanan publik pada aspek assurance memiliki skor total 1836. Jika dilihat pada kriteria pelayanan publik, maka pelayanan publik di Desa Songan B pada aspek assurance masuk dalam range skor 1612,8-1920 dengan kriteria sangat setuju. Pelayanan publik pada aspek emphaty memiliki skor total 1814. Jika dilihat pada kriteria pelayanan publik, maka pelayanan publik di Desa Songan B pada aspek emphaty masuk dalam range skor 1612,8 1920 dengan kriteria sangat setuju. Implementasi penggunaan dana desa untuk meningkatkan pelayanan publik di Desa Songan B memiliki skor total 8705 . Jika dibandingkan dengan kriteria pelayanan publik, maka implementasi penggunaan dana desa di Desa Songan B secara total masuk dalam range skor 80649600 dengan kriteria sangat setuju.

Implementasi penggunaan dana desa untuk meningkatkan perekonomian desa di 
Desa Songan B. Dapat ditinjau dari aspek infrastruktur yang baik, fasilitas yang memadai, akses informasi, sumber daya manusia yang unggul, pendapatan penduduk. Selanjutnya hasi penelitian atau

\begin{tabular}{llrr} 
perhitungan & mengenai & \multicolumn{2}{c}{ implementasi } \\
penggunaan & dana desa & untuk \\
meningkatkan perekonomian desa & dapat \\
dilihat & pada & tabel & 2.
\end{tabular}

Tabel 2. Implementasi Penggunaan Dana Desa untuk Meningkatkan Perekonomian Desa

\begin{tabular}{cccc}
\hline Keterangan & Skor Aspek & Range Skor & Kriteria \\
\hline Infrastruktur yang baik & 3129 & $2822,4-3360$ & Sangat Setuju \\
Fasilitas yang memadai & 857 & $806,4-960$ & Sangat Setuju \\
Akses informasi & 1330 & $1209,6-1440$ & Sangat Setuju \\
Kualitas Sumber Daya & 1191 & $1209,6-1440$ & Sangat Setuju \\
Manusia yang unggul & & & \\
Pendapatan penduduk & 799 & $652,8-806,3$ & Setuju \\
Skor total & 7306 & $6854,4-8160$ & Sangat Setuju \\
\hline
\end{tabular}

Berdasarkan tabel 2 di atas, dapat dijelaskan bahwa perekonomian desa pada aspek Infrastruktur yang baik memiliki skor total 3129. Jika dilihat pada kriteria perekonomian desa, maka perekonomian desa di Desa Songan B pada aspek infrastruktur yang baik masuk dalam range skor 2822,4-3360 dengan kriteria sangat setuju. Perekonomian desa pada aspek fasilitas yang memadai memiliki skor total 857. Jika dilihat pada kriteria perekonomian desa, maka perekonomian desa di Desa Songan B pada aspek fasilitas yang memadai masuk dalam range skor 806,4 960 dengan kriteria sangat setuju. Perekonomian desa pada aspek akses informasi memiliki skor total 1330. Jika dilihat pada kriteria perekonomian desa, maka perekonomian desa di Desa Songan B pada aspek fasilitas akses informasi masuk dalam range skor 1209,6-1440 dengan kriteria sangat setuju. Perekonomian desa pada aspek kualitas sumber daya manusia yang unggul memiliki skor total 1191. Jika dilihat pada kriteria perekonomian desa, maka perekonomian desa di Desa Songan B pada aspek fasilitas kualitas sumber daya manusia yang unggul masuk dalam range skor 1209,6-1440 dengan kriteria sangat setuju. Perekonomian desa pada aspek pendapatan penduduk memiliki skor total 799. Dilihat pada kriteria perekonomian desa, maka perekonomian desa di Desa Songan B pada aspek pendapatan penduduk masuk dalam range skor 652,8806,3 dengan kriteria setuju. Implementasi penggunaan dana desa untuk meningkatkan perekonomian desa di Desa Songan B memiliki skor total 7306. Jika dilihat pada kriteria perekonomian desa, maka implementasi penggunaan dana Desa Songan B secara total masuk dalam range skor 6854,4-8160 dengan kriteria sangat setuju.

Implementasi penggunaan dana desa untuk mengentaskan kemiskinan di Desa Songan B ditinjau dari aspek tingkat buta huruf, angka pengangguran, dan pekerjaan disektor informal. Selanjutnya hasi perhitungan mengenai implementasi penggunaan dana desa untuk mengentaskan kemiskinan dapat dilihat pada tabel 3.

Tabel 3. Implementasi Penggunaan Dana Desa untuk Mengentaskan Kemiskinan

\begin{tabular}{cccc}
\hline Keterangan & Skor Aspek & Range Skor & Kriteria \\
\hline Tingkat buta huruf & 797 & $652,8-806,3$ & Setuju \\
Angka Pengangguran & 884 & $806,4-960$ & Sangat Setuju \\
Pekerjaan di sektor informal & 1598 & $1305,6-1612,7$ & Setuju \\
Skor total & 3279 & $3225,6-3840$ & Sangat Setuju \\
\hline
\end{tabular}


Berdasarkan Tabel 3 di atas, dapat dijelaskan bahwa mengentaskan kemiskinan pada aspek tingkat buta huruf memiliki skor total 797. Jika dilihat pada kriteria mengentaskan kemiskinan, maka pengentasan kemiskinan di Desa Songan B pada aspek tingkat buta huruf masuk dalam range skor 652,8-806,3 dengan kriteria setuju. Mengentaskan kemiskinan pada aspek angka pengangguran memiliki skor total 884. Jika dilihat pada kriteria mengentaskan kemiskinan, maka pengentasan kemiskinan di Desa Songan B pada aspek angka pengangguran masuk dalam range skor 806,4-960 dengan kriteria sangat setuju. Mengentaskan kemiskinan pada aspek pekerjaan di sektor informal memiliki skor total 1598. Jika dilihat pada kriteria mengentaskan kemiskinan, maka pengentasan kemiskinan di Desa Songan B pada aspek pekerjaan di sektor informal masuk dalam range skor 3225,6-3840 dengan kriteria setuju. Implementasi penggunaan dana desa untuk mengentaskan kemiskinan di Desa Songan B memiliki skor total 3279. Jika dilihat pada kriteria mengentaskan kemiskinan, maka implementasi penggunaan dana Desa Songan $B$ secara total masuk dalam range skor 3225,6-3840 dengan kriteria sangat setuju.

\section{Pembahasan \\ Implementasi Penggunaan Dana Desa untuk Meningkatkan Pelayanan Publik di Desa Songan B}

Berdasarkan hasil penelitian penggunaan dana desa untuk meningkatkan pelayanan publik dilihat dari aspek tangible, realibility, responsiveness, assurance, emphaty sudah sangat baik. Hal ini terbukti dari proses pelayanan yang menjadi sangat mudah, dengan menggunakan alat bantu teknologi komputer, mesin fotocopy, merespon dengan cepat masyarakat yang ingin mendapatkan pelayanan tanpa ditundatunda, memberikan jaminan biaya kepada masyarakat sehingga dalam proses persyaratan pembuatan akte, KTP, KK tidak mengeluarkan biaya. Hal ini sesuai dengan pendapat (Mulyani, 2017) mengenai tujuan dana desa yaitu untuk meningkatkan pelayanan publik.
Masyarakat desa memiliki pendapat setuju, bahwa pelayanan publik sangat bermanfaat bagi kepentingan masyarakat ditinjau dari aspek tangible.Tangible atau bukti fisik yaitu kemampuan suatu pemerintah dalam menunjukkan eksistensinya kepada masyarakat. Penelitian ini membuktikan bahwa masyarakat desa merasakan manfaat terhadap penggunaan dana desa yaitu dengan pelayanan yang mudah masyarakat desa akan lebih mudah mendapatkan pelayanan mengenai persyaratan pembuatan KTP, KK, dan administrasi lainnya.

Masyarakat desa memiliki pendapat sangat setuju bahwa pelayanan publik ditinjau dari aspek realibility sudah baik. Realibility adalah Kemampuan petugas/aparatur dalam menggunakan alat bantu teknologi. Hal ini terbukti bahwa pelayanan yang dilakukan di Desa Songan B sudah menggunakan alat bantu teknologi seperti mesin fotocopy, komputer dan lainnya sehingga dapat memudahkan masyarakat desa dalam proses pelayanan administrasi kependudukan.

Masyarakat desa memiliki pendapat setuju, bahwa pelayanan publik desa ditinjau dari aspek responsiveness sudah baik. Responsiveness atau ketanggapan yaitu suatu kemampuan untuk membantu dan memberi pelayanan yang cepat (responsif) dan tepat kepada masyarakat, dengan penyampaian informasi yang jelas. $\mathrm{Hal}$ ini terbukti dalam proses pelayanan akte, KTP, KK, dan administrasi lainnya yang sebelumnya menghabiskan waktu lebih dari 3 hari menjadi hanya 2 hari. Hal ini menunjukan petugas/aparatur desa sudah melakukan pelayanan dengan waktu yang tepat dan cepat tanggap terhadap masyarakat yang ingin mendapatkan pelayanan.

Masyarakat desa memiliki pendapat sangat setuju, bahwa pelayanan publik ditinjau dari aspek assurance sudah baik. Hal ini terbukti dari proses pembuatan akte, KK, KTP dan administrasi lainnya yang tidak perlu mengeluarkan biaya banyak. Petugas/aparatur desa sudah memberikan jaminan legalitas sesuai dengan ketentuan yang berlaku. Hal ini akan membantu 
masyarakat dalam meringankan beban pelayanan.

Masyarakat desa memiliki pendapat sangat setuju, bahwa pelayanan publik ditinjau dari aspek emphaty sudah baik. Emphaty adalah memahami keinginan masyarakat dan melayani dengan tidak diskriminatif (membeda-bedakan). Hal ini terbukti dalam proses pelayanan pembuatan akte, KK, KTP, dan adminitrasi lainnya yang tidak membedakan masyarakat berdasarkan gender, status sosial, dan jenis kelamin sehingga menunjukan petugas/aparatur desa sudah bersikap sopan santun terhadap masyarakat yang ingin mendapatkan pelayanan. Masyarakat Desa Songan B memiliki pendapat sangat setuju terhadap penggunaan dana desa untuk meningkatkan pelayanan publik di Desa Songan B. Hal ini dapat dilihat dari skor total pada pelayanan publik yaitu sebesar 8705 dan masuk kriteria sangat setuju.

\section{Implementasi Penggunaan Dana Desa Untuk Meningkatkan Perekonomian Desa di Desa Songan B}

Berdasarkan hasil penelitian penggunaan dana desa untuk meningkatkan perekonomian desa dilihat dari aspek infrastruktur yang baik, fasilitas yang memadai, akses informasi, kualitas sumber daya yang unggul, pendapatan penduduk sudah baik. Hal ini terbukti dari akses jalan yang bagus, fasilitas sekolah, puskesmas yang memadai sehingga akan memacu terhadap pertumbuhan ekonomi. Hal ini sesuai dengan pendapat Mulyani (2017) mengenai tujuan dana desa yaitu untuk meningkatkan perekonomian desa.

Masyarakat desa memiliki pendapat sangat setuju, bahwa untuk meningkatkan perekonomian desa dilihat dari aspek infrastruktur sudah baik. Hal ini dapat dibuktikan dengan adanya aksesibilitas jalan yang bagus, drainase pedesaan, dan tersedianya infrastruktur untuk mendukung pangan seperti hasil pertanian dan kebutuhan dasar berupa penyediaan air bersih. Hal ini dapat mempermudah proses perekonomian desa.

Masyarakat desa memiliki pendapat sangat setuju bahwa penggunaan dana desa untuk meningkatkan perekonomian desa sudah baik dilihat dari aspek fasilitas yang memadai. Hal ini dapat dibuktikan dengan adanya fasilitas sekolah, puskesmas, yang memadai di Desa Songan $B$, sehingga masyarakat yang ingin sekolah tidak perlu jauh-jauh ke kota untuk mengenyam pendidikan dan berobat.

Masyarakat desa memiliki pendapat sangat setuju, bahwa penggunaan dana desa untuk meningkatkan perekonomian desa dilihat dari aspek akses informasi sudah baik. Hal ini terbukti bahwa sudah tersedia informasi mengenai pengelolaan keuangan, perencanaan, dan kemiskinan seperti pengeluaran untuk pembangunan dan kepentingan lainnya sehingga memudahkan masyarakat untuk mengetahui informasi tersebut.

Masyarakat desa memiliki pendapat sangat setuju bahwa penggunaan dana desa untuk meningkatkan perekonomian desa dilihat dari aspek kualitas sumber daya yang unggul sudah baik. Hal ini terbukti dari sebagian besar masyarakat sudah mengenyam pendidikan minimal tamatan SMA/SMK yang dulunya sebagian besar hanya tamatan SD dan SMP. Adanya penggunaan dana desa ini akan sangat bermanfaat bagi masyarakat.

Masyarakat desa memiliki pendapat setuju, bahwa penggunaan dana desa untuk meningkatkan perekonomian desa sudah baik dilihat dari aspek pendapatan penduduk. Hal ini terbukti dari sebagian besar masyarakat yang dulunya memiliki pendapatan di bawah rata-rata sekarang sudah di atas rata-rata nasional dan akan mempermudah pertumbuhan ekonomi desa. Masyarakat desa memiliki pendapat sangat setuju terhadap penggunaan dana desa untuk meningkatkan perekonomian desa. Hal ini dapat dilihat dari skor total pada perekonomian desa yaitu sebesar 7306 dan masuk kriteria sangat setuju.

\section{Implementasi Penggunaan Dana Desa Untuk Mengentaskan Kemiskinan di Desa Songan B}

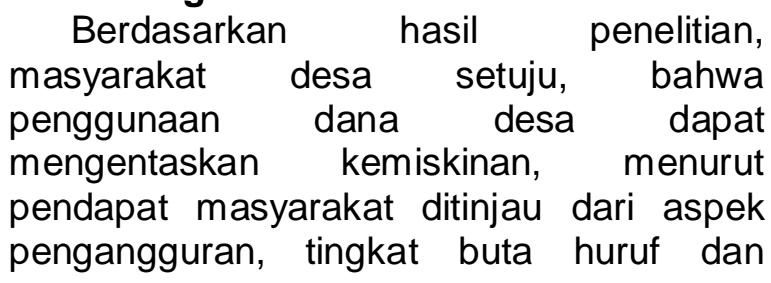


pekerjaan di sektor informal sudah baik. Hal ini dapat dibuktikan sebagian besar masyarakat yang dulunya menganggur sekarang sudah memiliki pekerjaan, serta yang dulunya sebagian besar masyarakat tidak bisa membaca dan menulis sekarang sudah berkurang. Hal ini sesuai dengan pendapat (Mulyani, 2017) tujuan dana desa yaitu untuk mengentaskan kemiskinan.

Masyarakat desa memiliki pendapat setuju, bahwa penggunaan dana desa dapat mengentaskan kemiskinan ditinjau dari aspek tingkat buta huruf. Hal ini terbukti dengan adanya penggunaan dana desa sebagaian besar masyarakat yang dulunya tidak mampu membaca dan menulis sekarang sudah berkurang sehingga akan mengurangi tingkat buta huruf di Desa Songan B.

Masyarakat desa memiliki pendapat sangat setuju, bahwa penggunaan dana desa untuk mengentaskan kemiskinan Desa Songan B sudah baik dilihat dari aspek angka pengangguran. Hal ini terbukti dari sebagian masyarakat yang dulunya tidak memiliki pekerjaan sekarang sudah memiliki pekerjaan yang layak, sehingga masyarakat yang menganggur sudah berkurang.

Masyarakat desa memiliki pendapat setuju bahwa penggunaan dana desa untuk mengentaskan kemiskinan Desa Songan B sudah baik dilihat dari aspek pekerja di sektor informal. Hal ini terbukti dari sebagian masyarakat desa yang dulunya bekerja di sektor pertanian saja sekarang sudah bekerja di sektor formal seperti guru dan tenaga kesehatan. Masyarakat desa memiliki pendapat sangat setuju terhadap penggunaan dana desa untuk mengentaskan kemiskinan. Hal ini dapat dilihat dari skor total pada pengentasakn kemiskinan yaitu sebesar 3279 dan masuk kriteria sangat setuju.

\section{SIMPULAN DAN SARAN Simpulan}

Berdasarkan hasil penelitian dan pembahasan dapat disimpulkan bahwa, implementasi penggunaan dana desa untuk meningkatkan pelayanan publik sangat bermanfaat untuk masyarakat. Hal ini dapat dilihat dari perolehan pada masing-masing aspek yaitu aspek tangible memiliki kriteria baik, aspek realibility memiliki kriteria sangat baik, aspek responsiveness memiliki kriteria baik, aspek assurance memiliki kriteria sangat baik, emphaty memiliki kriteria sangat baik (1814). Secara keseluruhan impelementasi penggunaan dana desa untuk meningkatkan pelayanan publik di Desa Songan B sudah masuk dalam kriteria sangat baik.

Implementasi penggunaan dana desa untuk meningkatkan perekonomian desa sangat bermanfaat untuk masyarakat. Hal ini dapat dilihat dari perolehan pada masing-masing aspek yaitu aspek infrastruktur yang baik memiliki kriteria sangat baik, aspek fasilitas yang memadai memiliki kriteria sangat baik aspek akses informasi memiliki kriteria sangat baik, aspek kualitas sumber daya yang unggul memiliki kriteria sangat baik, aspek pendapatan penduduk memiliki kriteria baik. Secara keseluruhan Impelementasi penggunaan dana desa untuk meningkatkan perekonomian desa masuk dalam kriteria sangat baik.

Implementasi penggunaan dana desa untuk mengentaskan kemiskinan di Desa Songan B sudah sangat baik. Hal ini dapat dilihat dari perolehan pada masing-masing aspek yaitu aspek tingkat buta huruf memiliki kriteria baik, aspek angka pengangguran memiliki kriteria sangat baik, aspek pekerjaan di sektor informal memiliki kriteria baik dan secara keseluruhan implementasi penggunaan dana desa untuk mengentaskan kemiskinan di Desa Songan $B$ masuk kriteria sangat baik.

\section{Saran}

Berdasarkan simpulan di atas, maka dapat diajukan saran yaitu, dengan adanya dana desa diharapkan Desa Songan B dapat meningkatkan pelayanan publik dari aspek tangible karena belum memadainya perangkat komputer, mesin fotocopy dalam proses pelayanan persyaratan pembuatan akte, KK, KTP dan administrasi lainnya. Pemanfaatan dana desa untuk tahun berikutnya agar menyediakan peralatan komputer dan mesin fotocopy yang memadai sehingga dapat mengoptimalkan pelayanan kepada masyarakat. Dilihat dari aspek responsiveness juga perlu ditingkatkan karena masih banyak 
$\begin{array}{llr}\text { masyarakat desa } & \begin{array}{c}\text { yang lambat } \\ \text { mendapatkan }\end{array} & \text { respon }\end{array}$ pegawai/perangkat desa sehingga nantinya pemanfaatan dana desa untuk tahun berikutnya dapat meningkatkan kompetensi sumber daya manusia. Perlu peningkatan sarana dan prasarana desa yang berhubungan dengan peningkatan pendapatan penduduk, misalnya kualitas akses jalan yang bagus, fasilitas sekolah yang memadai, pasar yang memadai sehingga akan mengurangi angka kemiskinan di Desa Songan B. Bagi peneliti selanjutnya dapat menganalisis faktorfaktor yang dapat meningkatkan dana desa.

\section{DAFTAR PUSTAKA}

Mulyani, Sri. 2017. Buku Pintar Dana Desa. Jakarta: Kementrian Keuangan Republik Indonesia.

Nurdin, Usman. 2002. Konteks Implementasi Berbasis Kurikulum. Bandung: CV Sinar Baru.

Sugiyono. 2011. Metode Penelitian Admiistratif. Bandung: Alfabeta.

$\begin{array}{ccc}2012 . & \text { Metode } & \text { Penelitian } \\ \text { Adminstratif } & \text { Dilengkapi } & \text { Dengan } \\ \text { Metode } R \& D \text {. Bandung: Alfabeta. }\end{array}$

- 2013. Metode Penelitian Kuantitatif, Kualitatif Dan R\&D. Bandung: Alfabeta.

Suharsimi, Arikunto. 2002. Prosedur Penelitian Pendekatan Suatu Praktek. Jakarta: PT Rineka Cipta.

- 2010. Prosedur Penelitian Suatu Pendekatan Praktik. Jakarta: Rineka Cipta.

Suharyono, Soemarwato. 2018. Catatan Penting Keindonesiaan Kita. Yogyakarta: Depublis.

Suryawati. 2004. Teori Ekonomi Mikro. Yogyakarta: Jarnasy.

Undang-undang nomor 25 tahun 2009 tentang pelayanan publik

Undang-undang nomor 6 tahun 2014 tentang pengertian Desa

Umar, Husein. 2005. Riset Sumber Daya Manusia. Jakarta: PT Gramedia
Pustaka Utama.

Windhu, Putra. 2018. Perekonomian Indonesia Penerapan Beberapa Teori Ekonomi Pembangunan Di Indonesia. Jakarta: PT Raja Grafindo Persada. 